\title{
Transatlantica
}

Revue d'études américaines. American Studies Journal

$1 \mid 2010$

American Shakespeare / Comic Books

\section{Interview of Darin Mickey, photographer and faculty member at the International Center of Photography}

Hélène Béade

\section{OpenEdition}

Journals

Electronic version

URL: https://journals.openedition.org/transatlantica/4959

DOI: $10.4000 /$ transatlantica.4959

ISSN: $1765-2766$

Publisher

Association française d'Etudes Américaines (AFEA)

\section{Electronic reference}

Hélène Béade, "Interview of Darin Mickey, photographer and faculty member at the International Center of Photography", Transatlantica [Online], 1 | 2010, Online since 28 September 2010, connection on 10 February 2023. URL: http://journals.openedition.org/transatlantica/4959 ; DOI: https://doi.org/ 10.4000/transatlantica.4959

This text was automatically generated on 10 February 2023.

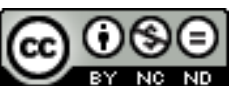

Creative Commons - Attribution-NonCommercial-NoDerivatives 4.0 International - CC BY-NC-ND 4.0 https://creativecommons.org/licenses/by-nc-nd/4.0/ 


\title{
Interview of Darin Mickey, photographer and faculty member at the International Center of Photography
}

\author{
Hélène Béade
}

\section{AUTHOR'S NOTE}

Darin Mickey is a photographer and a faculty member at the International Center of Photography' ${ }^{1}$. He was interviewed at his home in Brooklyn, NY, on April 22, 2010.

\section{The I.C.P. course}

\begin{abstract}
HB : - You are teaching a course at the ICP "The political landscape. Reaction through images." Could you first describe it?

DM : The title plays on the phrase "the political landscape," how we hear it in a news context or from a political pundit, talking about red state/ blue state, reappropriating its meaning towards the context of photography. The core being that almost every photograph has a political component to it. Some are more overt or obvious than others. The "reaction through images" is something I would like to drop from the title in the future. I don't want it to be interpreted so literally. It's important for the students to remain open to different ways of interpreting what they are photographing. I don't want them to feel hemmed in by the history of "concerned" photography.
\end{abstract}


HB : - Did you create this course?

DM : I proposed the course and created the outline for it a couple years ago. The first one ran in 2008, and then 2009. We'll see where it goes from there and how it changes.

HB : - When you created your class, were you also thinking of environmental landscape?

DM : Inevitably the environmental and political aspects tend to go hand in hand. Whatever the subject may be (urban sprawl, industrial pollution, re-zoning of neighborhoods, etc.), there are strong parallels.

HB : - There are, of course, time constraints because the course lasts only one semester, so students are 'encouraged to work within the New York area.' New York City is too far from the large open spaces (I am thinking of fieldwork by photographers like Edward Burtynsky or David Maisel), so what is a landscape photographer to do when living and working in New York City? Where do they go or where do you encourage them to go ?

DM : When I first proposed the course I thought 'is this going to be a problem?' but actually it seems it to be one of the strengths of the class. Being in New York challenges the students and myself to re-think the definition of a landscape photograph. In New York, there is very little horizon. It can be difficult to make sense of the space here, it's very crowded and covered in concrete. So where is the land? Under the street, beneath the sidewalk and the horizon is often obscured by buildings. It definitely does not lend itself to the wide expanses that we are used to thinking of in landscape photography, of the West and various other places, pictures in more rural settings. I find how the students have to adapt to that and approach it quite interesting. A lot of the time they end up pulling in, working with a different sense of scale. Questioning the idea of a landscape. It doesn't always have to be a very large space. It can be a very finite space, on the sidewalk. You end up seeing a lot of photographs that are dealing with questioning the definition of landscape. So what was initially seen as a problem can be viewed as an attribute to the place where they have to work.

HB : - If you look at a map, to be geographically more precise, what are the places in or around New York City that are interesting? Are there any landfills?

DM : I guess when most people think of photography in New York City, they think of street photography. I'm amazed as a pedestrian walking and going out to the periphery of the city, there are wetlands, the Gowanus Canal running through Brooklyn, there are many complex environmental things going on here. It is often under the surface. So at first you see this post-industrial city in transformation. North of here, where we are now in Greenpoint, Brooklyn, is the site of one of the largest oil spills in the history of the country. It's there underneath the neighborhood. So how you photograph that presents a challenge. It is possible. It's not going to lead to the images one might at first envision. It will not render the same images as say, the Valdez oil spill where you have wildlife being pulled out of sludge. The students as well as myself are forced to look more around the corners and do some urban archeology to find the source of some material.

\section{Political landscape photography today}


HB : - In the 19th century, the landscape of American photography was that of the West Now it's all over the place...

DM : I think so. One thing is that photography has such a short history. You see a resurgence of work especially, very influenced by the work of 30 or 40 years ago. Perhaps it is not resurgent? The issues those photographers were dealing with are still very relevant today. So the things they were confronting and how they were going about it still echo today. There is a continuation. I like it when I see photographs that are not just following in a straight line what the New Topographers where doing. Hopefully there is an element that makes them unique to this period in time.

HB : - What is new and how does the new generation distinguish itself from this heritage according to you?

DM : That is a bit of an impossible question. I am trying to figure that out myself and will surely never find the answer. One thing I enjoy about teaching is that it allows me to step outside my own process and see how other people work through these questions visually. I think it helps not staying inside a "photography vacuum," to be aware of the ways writers, filmmakers, and other visual artists comment on and interpret the world. The writings of John McPhee, James Howard Kunstler, Rebecca Solnit, and John Brinkerhof Jackson were very important sources of influence in shaping the ICP class for instance.

With that being said, there are a lot of photographers out there making really fresh and interesting work.

HB : - Could you please talk about these photographers who work in or around New York City?

DM : I don't feel totally comfortable giving my opinions on other photographers' work in an interview. I'm definitely not the most qualified critic. I can tell you some of the people whose work inspires me and who I feel have really unique ways of interpreting the landscape.

The first one to come to mind would be, Ed Panar ${ }^{2}$, a good friend of mine. I got to know Ed through the process of publishing a book with J\&L Books, as we were on press at the same time. Ed was publishing his book, Golden Palms (Plates 1 and 2) ${ }^{3}$, work made in Los Angeles. He now lives in New York and has been taking pictures here as well. Actually, Ed seems to take pictures all over the place. A big part of what I like about Ed's photographs is that there is a sense of humor in them without being goofy, humor with a pinch of nihilism (Plates 3, 4 and 5). They also have the feeling of taking a long walk and seeing the world from a pedestrian scale. Finding your way by getting lost. I don't even think he has a driver's license. No helicopters or cranes are involved.

Ron Jude's book ${ }^{4}$, Other Nature, from last year, is something I've been looking at a lot lately. Very quiet and beautiful pictures of anonymous American places. Great edit and pace to the book.

Mark Steinmetz ${ }^{5}$ 's trilogy of books, Greater Atlanta, Southeast, and South Central. Beautiful black and white photographs that say a lot about America with a very contemporary eye, really inspiring work.

Justine Kurland's recent show Train Bound for Glory at Mitchell-Innes \& Nash ${ }^{6}$. Those pictures cover many bases. They deal with the broader social issues of transitory 
living or homelessness and out of a context that we normally associate with them. The images are also a tender diary of her relationship with her son. Being a single mother, living out of a van, traveling around taking those pictures, she is really living that work.

HB : - How important is the choice of the photographic tool ? And what do you think of the extensive use of the large format print. It seems that, in landscape photography, the prints are quite big?

DM : - It definitely lends itself to that. You are often photographing big spaces and there is naturally a desire to present them big. Then you look at a show of Robert Adams' smaller black and white prints and they are so intimate and powerful. The prints draw the viewer in on a more human scale. I tend to lose interest when the prints are gigantic. It draws too much attention to the process and money. When you have to stand 30 feet away to view a picture and it could still crush you if it came loose from the wall?

HB : - It makes me think of the use of the 'technological sublime' like in Burtynsky's show Oil. What did you think of it?

DM : - There are some very powerful photographs in that show, the landscape and man's imprint upon it on a grand scale. When I see those aerial shots of large-scale mining operations, I walk away feeling somewhat ashamed of the technology that allows destruction on that scale and at a rate that is obviously unsustainable. Nature presented us with the Grand Canyon and our contribution or legacy is strip mines and mountains filled with radioactive waste.

$\mathrm{HB}$ : The choice of subject and the use of an aesthetic are both disturbing and paradoxical; it's beautiful yet the subject is not. Does an environmental landscape photograph have to be beautiful? There is a paradox in this. Does an environmental landscape photograph have to be beautiful?

DM : - A beautiful photograph of something horrific can be very effective. Think of Mitch Epstein"s or John Pfahl's's pictures of power plants: these are beautiful pictures with their sunsets, but they are also disturbing because there is a nuclear power plant in the frame. The power in those pictures is their beauty. Warm late afternoon or early morning light played off the fact that people live in such close proximity and go about their lives next to nuclear reactors.

$\mathrm{HB}$ : How important is the statement of the photographer on the environment? Do you think sometimes the photograph is politically powerful because of that statement, or is it politically powerful by itself?

DM : - It depends on the work. If the work is about a big oil spill under Brooklyn, then text could be a very important element in conveying that information to the viewer. In Taryn Simon's book, An American Index of the Hidden and Unfamiliar the writing is very important. The pictures are beautiful and stand on their own but the text brings so many important layers of information to the work.

\section{Your own work}

HB : - Do you work in or around New York City?

DM : - I've lived in New York since the early nineties and it's only over the last 2 years that I have taken pictures actively here. For a long time it was a very separate process, which meant going back to the Midwest where I grew up, outside of the city. 
New York was always sort of a complicated place for me visually. I love living here. I am just now finding a way to take pictures here and it involves taking long walks. When I would photograph in the Midwest or other places, I would be driving around in a car mainly. I'm really interested now in looking at the world as a pedestrian, at three miles an hour or whatever the average speed of a person is. I enjoy walking around and seeing things from a human scale. It's very different from when I take pictures in say, an office. There are more logistics involved in that process (get access, schedule a time to be there, bring lights, etc). Walking around with a camera gets me back to what initially interested me in photography. Exploring what you think you already know and seeing it totally different in a photograph. Having less certainty when I take a picture. I like that feeling. Taking these longer walks is sort of "multi-tasking" in a way. I get a lot of thinking done. My brain will go places that it doesn't when I'm sitting still.

$\mathrm{HB}$ : - Do you work with the same camera?

DM : - It depends on what I'm photographing. When I'm walking I try and keep it simple. I have my backpack with a medium format camera, small portable flash, battery, and a water bottle.

HB : - Where do you like to go?

DM : - I start from my house and try to head in a different direction each time. There is overlap because I do a lot of zig-zagging and walking in circles. I usually have a final destination or turning-around point in mind. It is usually eight or ten miles away. One time I walked the length of Flatbush Avenue out to the old airstrip at Floyd Bennett Field. I also like to wander around the few remaining industrial neighborhoods in Queens and Brooklyn. I don't bring a map and if I'm lucky, maybe I'll get a little lost.

HB : - What do you focus on?

DM : It is a case where the pictures have started to tell me more what I am focusing on. First the sidewalk, because that's what I'm often looking at, trying not to step in dog shit. I'm also trying not to get hit by a car. I do make more of an effort to look up now. It still ends up being a lot of pictures of things on the sidewalk.

I realize I am still using traditional landscape framing. The horizon might be the line that meets a sidewalk to a building and the sky might be the paint on a building, or bricks, the tree line is weeds shooting out of the sidewalk. Standing over a plastic bag is as close as I get to an aerial photograph.

HB : - Is it pushing the landscape to its limits?

DM : - For me it is at this point in time. Many people have pushed it much further. I keep going back to this question: "What is a landscape?" and for me it basically comes down to: "a landscape photograph is any photograph taken on land," on earth. Pretty vague and open ended.

That is an element of photography I love, the feeling of being an observer, an alien observer dropped to earth.

HB : - There is a series called " On land" (Plate 6) in your work.

DM : Yeah, those pictures for me stem from that feeling of being an outside observer looking at these often common environments. They are from various places: Detroit, Japan, Kansas City, New Jersey, St. Louis, Denver, etc. 
HB : - You focus a lot on the floor, or on walls, as if you were bumping into something. Is that a choice linked to the environmental crisis?

DM : - Not consciously. I often like what people put on walls and what they sometimes drop on the floor. It's not like: "I would be taking a picture of a tree and the sky if that damn wall wasn't in the way!"

HB : - When you are in the city, is it difficult to step back?

DM : - Instead of not taking pictures somewhere because there is a building in the way of something more idyllic, deal with the buildings, roads, and wires (Plates 7, 8 and 9). A lot of photographers are dealing with that. It's the world most people live in. It's not as clear as: "I'm really upset about this, and this makes me infuriated" or, "I'm taking pictures of trash (Plate 10) because I want to solve the problem of littering and confront the narcissism of people who do not care about the world." There is an element of that. There are also a lot of more selfish motivations. I want to solve some sort of visual puzzle. I want to make something that is ugly feel beautiful, at least to me. There is a selfish side to it (Plate 11).

It can be a challenge photographing places that are inherently ugly or visually confrontational. I find it to be much more difficult in pristine, beautiful nature. I rarely take serious photographs in that type of environment. There is no conflict for me and I seem to need conflict.

HB :- I saw in your book that your father sells abandoned mines ${ }^{10} \ldots$

DM : -Yes, he sells storage space in old limestone and salt mines in the Midwest. The landscape is an important element in that group of pictures about my father. The highway he drives to work on everyday. The backyard my parents rarely use (Plate 12). The entrance to his office in the cave (Plate 13). The house in a new suburban development, which is not in fact my parents' house but an example of their "dream house" (Plate 14). A place they aspire to live in one day.

I guess the landscape has always been important to me. I wasn't always as aware of it. I am more now when I look at the photographs I've taken. Definitely when I photograph I tend towards straight lines, there are certain compositions I repeat a lot and there are certain kinds of light I am attracted to. It is usually a more even light, not very romantic.

HB : You are going to teach a new class at the ICP soon, "Postcards From Real Worlds". What is the concept of this new class?

DM :- I'm still in the process of hammering that out. It will have similarities in structure to the "Political Landscape" course, with more of an emphasis on documentary projects. Looking at new ways of interpreting and presenting reality based subjects. A lot of what will shape the course will depend on the students and what they bring to the class as individuals. I'm looking forward to the challenges and work that will come out of the class. 


\section{NOTES}

1. The ICP was created by Cornell Capa in 1974. The International Center of Photography, located in the heart of New York City, is a museum and school «dedicated to the understanding and appreciation of photography " (http://www.icp.org/about-icp).

2. http://www.edpanar.com/

3. Ed Panar, Golden Palms. http://www.jandlbooks.org/GP.html

4. http://web.mac.com/ronjude/iWeb/ronjude/Ron\%20Jude\%20Landscapes.html

5. http://www.marksteinmetz.net/

6. http://www.miandn.com/\#/exhibitions/2009_10_chelsea_justine_kurland/

7. http://www.mitchepstein.net/

8. Power Places, 1981-1984: http://johnpfahl.com/pages/powerplaceseast/ eastwestpowerplacemenu.html

9. http://www.tarynsimon.com/

10. 'In 2001, Darin Mickey began to document his father's life at work and at home. Stuff I Gotta Remember Not To Forget is a portrait of Ken Mickey, who sells storage space in converted caves and abandoned mines throughout Kansas. (http://www.jandlbooks.org/stuff.html)

\section{INDEX}

Subjects: Trans'Arts

\section{AUTHOR}

\section{HÉLÈNE BÉADE}

Université Paris VII 